\title{
Okuljunk belöle! - Az oktatás szerepe a szúrt és vágott sérülések megelözésében
}

\author{
Let's learn from it! - The role of education in the prevention of stab and cut injuries
}

Sinka Lászlóné Adamik Erika1,2, Dr. Balogh Zoltán ${ }^{3,4}$,

1 Semmelweis Egyetem, Egészségügyi Közszolgálati Kar, Egészségügyi Menedzserképző

Központ, Budapest, ${ }^{2}$ NEVES Egyesület a Betegbiztonságért, Budapest,

${ }^{3}$ Semmelweis Egyetem, Egészségtudományi Kar, Budapest, ${ }^{4}$ Magyar Egészségügyi

Szakdolgozói Kamara, Budapest

Bevezetés: Az éles, hegyes eszközök okozta sérülések mindennapi kockázatként vannak jelen az egészségügyben dolgozók életében. A megelőzésük mind a sérülések elkerülése érdekében, mind pedig a fertőződés kockázata miatt fontos.

Célkitüzés: Közleményünkben megvizsgáljuk az éles, hegyes eszközök okozta sérülések megelözését célzó oktatások eredményességének fejlesztési lehetőségeit a kutatási eredmények és a publikált szakirodalmak tükrében.

Módszer: A témában készült, 2020-ban megjelent kutatás, valamint az azóta publikált szakirodalmak alapján fogalmazunk meg javaslatokat az oktatások rendszerére és módszerére, valamint az oktatandó tananyagra vonatkozóan.

Eredmények: Az oktatás az ismeretek bővítésén és a viselkedés megváltoztatásán keresztül eredményesen alkalmazható a sérülések megelőzésében. A hazai kutatás eredményei azt támasztják alá, hogy a téma oktatása annak tartalmát és gyakoriságát illetően is fejlesztendő.

Megbeszélés: A jogszabálynak megfelelő tartalommal felépített oktatási anyag hangsúlyait célszerü az intézményben azonosított problémákhoz igazítani. A képzés megfelelő gyakorisága fontos eleme az eredményességnek. A javasolt képzési forma a helyszínspecifikus gyakorlati oktatás.

Következtetés: Az éles, hegyes eszközök okozta sérülések kockázatát önmagában egyetlen módszer sem tudja nullára csökkenteni. A megelőző intézkedéseknek azonban nélkülözhetetlen eleme a megfelelő oktatás.

Background: The risk of injuries caused by sharp, pointed tools is always present in the everyday work of the healthcare staff. The prevention of these is necessary to avoid injuries and because of the risk of infection.

Objective: In this paper, we examine the possibilities for improving the effectiveness of education for the prevention of injuries caused by sharp, pointed tools in the light of the research results and the published literature.

Method: Based on the research carried out on the topic and published in 2020, as well as the literature pub- lished since then, we formulate proposals for the system and method of education and the curriculum to be taught.

Results: Education can be used effectively to prevent injuries by expanding knowledge and changing behaviour. The results of the Hungarian research support that the teaching of the topic should be improved in terms of its content and frequency.

Discussion: It is advisable to adapt the emphasis of the educational material elaborated initially in accordance with the regulation to the concrete problems identified in the institution. Adequate frequency of education is an important element of effectiveness. The recommended form of education is site-specific practical training.

Conclusion: No method alone can reduce the risk of injury from sharp instruments. However, adequate education is an essential element of preventive action.

\section{BEVEZETÉS}

Az éles, hegyes eszközök által okozott szúrásos, vágásos sérülések igen nagy arányban fordulnak elő az egészségügyi ellátást nyújtó személyzet körében. Szakirodalmi adatok szerint egyes szakmacsoportokban (pl. sebészek, mentősök) a sérülések aránya elérheti akár a $80-90 \%-o t$ is $[1,2]$.

E sérülések fő veszélye legtöbbször nem is a sérülések súlyosságában rejlik. A NEVES jelentési rendszerbe érkezett adatok elemzésére épülő kutatás szerint a jelentett esetek többségében (86,7\%-ában) közepes súlyosságú sérülés történt, azaz a bőr folytonossága megszakadt és a sérülés vérzéssel járt. $A$ felületes sérülések, vérzéssel nem járó karcolások, horzsolások aránya 9,1\% volt. Mindössze az esetek 4,2\%ában jelentettek súlyos sérülést, ami definíció szerint mély, erős vérzéssel járó szúrt sebet vagy vágott sebet jelent [3]

E sérülések legfőbb veszélye a vérrel, testnedvvel terjedő fertőző betegségekben rejlik, hiszen többek közt hepatitis B-, hepatitis C-vírussal, vagy HIV-vel fertőződhetnek a sérültek [2].

A hazai kérdőíves kutatás során 4031 fő válaszolt arra a kérdésre, hogy ő maga szerzett-e vér útján terjedő fertőzést a munkahelyen bekövetkezett éles, hegyes eszköz okozta 
balesettel összefüggésben. A válaszolók 2,3\%-a (összesen 92 fő) azt jelölte, hogy igen, ő megfertőződött, 7,2\%-ban pedig nem tudták, hogy megfertőződtek-e. A válaszadók 90,5\%-a állította biztosan, hogy nem szerzett fertőzést [3].

Ez is mutatja a prevenció fontosságát, amelynek a sérülés megelőzésén túl a fertőződési kockázat csökkentésére is ki kell terjednie.

\section{CÉLKITÜZÉS}

Az éles, hegyes eszközök okozta sérülések megelőzésének egyik közismert, és nagyon fontos eszköze az oktatás. És bár az oktatás széles körben alkalmazott gyakorlat, de annak minősége, eredményessége igen különböző lehet. Közleményünkben megvizsgáljuk az éles, hegyes eszközök okozta sérülések megelőzését célzó oktatások eredményességének fejlesztési lehetőségeit a kutatási eredmények és a publikált szakirodalmak tükrében.

\section{MÓDSZER}

A cikk írásakor a 2020-ban megjelent Éles, hegyes eszközök okozta sérülések okai, a megelőzés lehetőségei című tanulmányban közölt adatokból indultunk ki, és emellett áttekintettük a tanulmány elkészítése óta megjelent, a témához kapcsolódó legfrissebb szakirodalmakat is.

Az említett tanulmányban szereplő adatok a NEVES jelentési rendszerbe érkezett 860 esemény tényszerü adatainak elemzéséből származnak. A jelentési rendszerben annak indulása óta - van lehetőség a bekövetkezett sérülések jelentésére, amelynek adatlapja a Tüszúrás, éles eszköz okozta sérülések címet viseli. A jelentett adatok önkéntes és anonim adatszolgáltatás keretében kerültek be az országos adatbázisba. A NEVES jelentések feldolgozása a korábban publikált módszertan alapján történt [3].

A tanulmányban található másik adatsor forrása a Magyar Egészségügyi Szakdolgozói Kamarával (továbbiakban: MESZK) együttműködésben végzett anonim kérdőíves felmérés, amelyre összesen 5652 válasz érkezett. Az eredmények feldolgozása mindkét adatsor esetében az adatminőség ellenőrzésével és a duplikátumok kizárásával kezdődött. Az adatok statisztikai módszerek segítségével kerültek elemzésre. A tanulmány készítésének részét képezték szakértői egyeztetések is az egészségügyi ellátás különböző területein dolgozó munkatársak bevonásával, valamint sor került a témában megjelent hazai és nemzetközi szakirodalmak áttekintésére az azokban közölt, szúrásos vagy vágásos sérülésekhez vezető okok, valamint megelőzési lehetőségeik összegyűjtése céljából. A tanulmány készítéséhez az irodalomkeresés 2018-ban történt, összesen 79 forrás került áttekintésre. Az anyagban 40 szakirodalmi hivatkozás szerepel [4].

A jelen cikk készítése során áttekintettük a 2018 óta megjelent újabb közleményeket. $A$ hazai szakirodalmakat a MATARKA, a MOB és az MTMT adatbázisokban kerestük a „tüszúrás*”, „éles”, „hegyes”, keresőszavak használatával, de a témába illeszkedő közleményt nem találtunk. Külföldi szakirodalmakat a PubMed adatbázisban kerestünk. Az alkalmazott keresőszó-összetétel: „needlestick injur” OR sharp injur* AND (prevent* OR caus*)" volt, a következő szűrők mellett: Full text, Meta-Analysis, Systematic Review, Humans, English, from 2018/1/1 - 2021/8/1. Az így talált, cím és absztrakt alapján szűrt 6 releváns irodalmat kézi kereséssel még további forrásokkal bővítettük. A jelen cikkben összesen 9 forrást használtunk fel.

A frissen megjelent irodalmakat áttanulmányozva azt találtuk, hogy a legtöbb a megelőzést célzó oktatás kérdéskörét érinti, ezért döntöttünk úgy, hogy az ezzel kapcsolatos legfontosabb megállapításokat, megfontolandó javaslatokat ismertetjük cikkünkben.

\section{EREDMÉNYEK}

\section{A hazai helyzet rövid bemutatása}

A tűszúrásos, vágásos sérülések megelőzése érdekében végzett képzésekről és azok eredményességéről képet kaphatunk az Éles, hegyes eszközök okozta sérülések okai, a megelőzés lehetőségei című tanulmányban közölt adatokból.

A kutatás során végzett felmérés egyik kérdése azt vizsgálta, hogy a képzések milyen gyakorisággal történnek és milyen információkra terjednek ki. Hazánkban jogszabály írja elő az erre vonatkozó követelményeket. Ez az 51/2013. (VII. 15.) EMMI rendelet, amelynek a címe: az egészségügyi szolgáltatás keretében használt, éles vagy hegyes munkaeszközök által okozott sérülések megelözésére, az ilyen eszközök használatából eredő kockázatok kezelésére, valamint az egészségügyi tevékenységet végző személyek tájékoztatására és képzésére vonatkozó követelményekröl, lásd 1. táblázat.

8. § (1) A munkáltató gondoskodik arról, hogy a munkavállaló és a munkavédelmi képviselö - tájékoztatás és képzés (a továbbiakban együtt: képzés) formájában-elégséges és megfelelő információt kapjon

a) az egészséget fenyegető kockázatokról,

b) az expozíció megelőzését szolgáló intézkedésekröl,

c) az éles vagy hegyes eszközök biztonságos használatára vonatkozó elöírásokról,

d) az egyéni védőeszköz viseléséröl és használatáról,

e) az elöre nem látható veszélyhelyzetek megelözéséröl,

f) az éles vagy hegyes eszközök által okozott sérülések esetén teendő intézkedésekröl és

g) a vonatkozó hatályos jogszabályi rendelkezésekröl.

(2) A munkáltatónak a munkavállalót a munkába állás előtt, ezt követően évente kell képzésben részesítenie, és annak elvégzését írásban kell dokumentálnia.

(3) A (2) bekezdésben foglaltaktól eltérően a munkáltató a munkavállalót soron kivül képzésben részesíti

a) új kockázatok megjelenésekor vagy a kockázatok megváltozásakor továbbá

b) a munkavállaló használatában lévő éles vagy hegyes eszköz által okozott sérülést követően.

\section{1. táblázat}

Az oktatás gyakoriságára és tartalmára vonatkozó jogszabályi elöírás [5]

A kutatás választ keresett arra a kérdésre, hogy vajon milyen arányban valósulnak meg a jogszabályban megfogalmazott, képzéssel kapcsolatos elvárások. A válaszadók ( $n=4202$ ) 93,1\%-a vallotta azt, hogy iskolarendszerü tanul- 
mányai során megismerte az éles, hegyes eszközök okozta sérülések kockázatait. 4,7\%-uk nem emlékszik rá biztosan, 2,2\% pedig azt jelezte, hogy nem ismeri ezeket a kockázatokat. A munkahelyi képzések egy kissé más képet mutatnak ( $n=4223$ ). A kérdőív kitöltőinek már csak 80,3\%-a jelezte azt, hogy kapott a munkája során képzést ezzel kapcsolatban. 10,9\%-uk nem vett részt munkahelyi képzésen a témában, 8,7\%-uk nem emlékszik erre biztosan [4].

A vonatkozó rendelet szerint a munkáltatónak legalább évente képzésben kell részesítenie az érintett munkavállalókat. A visszajelzések alapján a felmérést megelőző 1 éven belül a válaszadók ( $n=4223$ ) 40,0\%-a részesült képzésben, 57,6\%-uk nem vett részt ilyen továbbképzésen. 2,4\%-ban nem tudták megválaszolni a kérdést [4].

Tovább árnyalja a képet, ha a jogszabályban felsorolt oktatandó témakörök mindegyikét külön-külön megnézzük, hogy azok részét képezték-e az oktatott tematikának. Az erre vonatkozó kérdést 2522 fő válaszolta meg. Ennél a többszörös választási lehetőséget biztosító kérdésnél a 7 válaszlehetőségből az összeset senki sem jelölte meg. 6 témát jelölt meg a kitöltők 25,1\%-a, 5 témát jelölt 17,1\%, 4 témát 23,9\%, 3 témát $18,5 \%$, 2 témát $9,7 \%$. A válaszadók 5,8\%-a mindöszsze egy témát jelölt meg a képzés tananyagaként. A leggyakrabban oktatott 3 téma: az éles vagy hegyes eszközök biztonságos használatára vonatkozó előírások (90,0\%), az éles vagy hegyes eszközök által okozott sérülések esetén teendő intézkedések (84,8\%), és az egyéni védőeszközök használata (79,1\%). A legkevesebb jelölést (40,4\%-ban) az elöre nem látható veszélyek megelőzésének témaköre kapta, lásd 1. ábra [4].

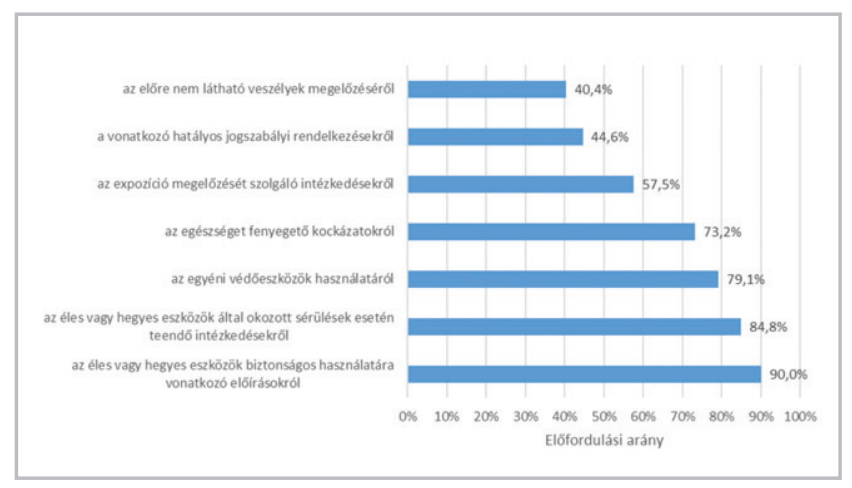

1. ábra

A továbbképzés témája ( $n=2522 ;$ többszörös választás) [4]

\section{Az oktatás jelentősége}

Egy iráni vizsgálat tapasztalatai azt mutatták, hogy azok az egészségügyi dolgozók, akik nem vettek részt a sérülések megelőzését célzó képzéseken, szignifikánsan (30\%-kal) nagyobb valószínűséggel szenvedtek el sérülést munkájuk során, mint azok, akik elvégezték a képzést. A 10 évnél kevesebb gyakorlati tapasztalattal rendelkező egészségügyi dolgozók 43\%-kal nagyobb valószínűséggel szereztek szúrt, vagy vágott sérülést, mint a 10 évnél nagyobb tapasztalattal rendelkező munkavállalók, ami szintén szignifikáns különbséget jelentett [6].
A hazai adatokat érintően érdemes ismét a már említett tanulmányt elővenni. A megtörtént esetek adatait gyűjtő NEVES jelentési rendszerben 698-an válaszoltak arra a többszörös választásos kérdésre, hogy esetükben mi játszott szerepet a sérülés kialakulásában, munkaeszköz, környezeti tényező, vagy személyi tényező? A válaszadók 56,7\%-a szerint az adott esemény létrejöttében a személyi tényezőnek szerepe volt, lásd 2. ábra [4].

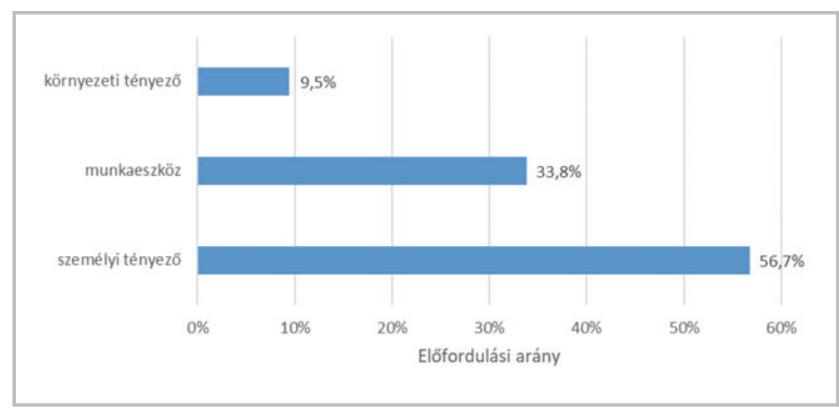

\section{2. ábra}

A sérülés bekövetkezésében szerepet játszó tényezók ( $n=698$; többszörös választás) [4]

Cheetham és munkatársai egy metaanalízis eredményeként azt közölték, hogy az oktatás 34\%-kal csökkentette az éles, hegyes eszközök okozta sérülések arányát, míg a védelemmel ellátott biztonsági eszközök használatának bevezetése az esetek előfordulásának 49\%-os csökkenéséhez vezetett. Érdemes azonban tudni azt, hogy a legeredményesebb megoldás a két módszer kombinálása volt. Az oktatás és a biztonsági eszközök használatának bevezetése együttesen a sérülések gyakoriságának $62 \%$-os csökkenését eredményezte [7].

Aziz és munkatársai közleményükben felhívták a figyelmet arra, hogy bár a biztonsági eszközök képesek csökkenteni a szúrásos, vágásos sérülések keletkezésének arányát, sérülések a biztonsági eszközök használata mellett is előfordulhatnak. Egyetlen általuk vizsgált tanulmány sem számolt be arról, hogy a biztonsági eszközök alkalmazásával sikerült volna felszámolni a sérüléseket. Kiemelték, hogy fontos a munkatársakban tudatosítani mindezt, és fokozott óvatossággal kell eljárni új eszközök bevezetésekor [8]. Ennek tudatosítására is kiváló alkalmat teremtenek az oktatások.

\section{Az oktatás javításának lehetőségei}

Cheetham és munkatársai kutatásuk eredményként arra a következtetésre jutottak, hogy az oktatás rövidtávon kedvező hatással lehet az éles, hegyes eszközök okozta sérülésekkel kapcsolatos ismeretekre és a prevenció szempontjából helyes viselkedésre, azonban az oktatás eredményességének mértékét és hosszútávú hatását illetően kétségeket fogalmaztak meg [7].

Treviño és munkatársai az orvostanhallgatók körében vizsgálták a vérrel terjedő fertőzések gyakoriságának csökkentési lehetőségeit. Megállapításuk szerint a hallgatókat az egyes gyakorlati helyszínek közötti váltás előtt helyszínspecifikus oktatásban célszerü részesíteni [9]. 
Az angol Nemzeti Egészségügyi Szolgálatnál (National Health Service, NHS) az egyik leggyakrabban alkalmazott képzési módszer az e-learning. Aziz és munkatársai azonban nem javasolják ennek a módszernek az alkalmazását az éles, hegyes eszközök okozta sérülések megelőzését célzó oktatások esetén, mert nem ad lehetőséget a tanultak eszközös gyakorlására, nem teszi lehetővé a vitát, visszakérdezést. Ezek negatívan befolyásolhatják a képzés eredményességét, a megszerzett ismereteket. A szerzők a képzés fejlesztési teendői között célként határozták meg az egészségügyi dolgozók bevonását, az oktatók kreativitásának növelését, a képzések érdekesebbé és tartalmasabbá tételét. A képzési formák közül a gyakorlati képzést eredményesebbnek gondolják, mint az e-learninget [8].

\section{MEGBESZÉLÉS}

A kutatás eredményei alapján a jogszabályban megfogalmazott, képzéssel kapcsolatos elvárásoknak való megfelelés jelentősen fejleszthető. Az iskolarendszerü képzés során az ismeretek átadása alaposabb, az intézményi szervezésủ képzések esetében nagyobb hiányosság tapasztalható e téren. A kérdést megválaszoló több mint kétezerötszáz személy közül senki sem jelölte meg a lezajlott oktatás témái között a jogszabályban felsorolt mind a 7 témát. Különösen problémásnak túnik emellett az oktatások megfelelő gyakorisággal történő megrendezése, az előirás szerint évenként ismétlődő oktatás a visszajelzések alapján csupán 40,0\%-ban valósult meg [4].

A külföldi szakirodalmak hangsúlyozzák az oktatás szerepét a megelőzésben. Saját kutatásunkban a bekövetkezett sérülések adatainak elemzése során azt találtuk, hogy 56,7\%-ban személyi tényező is szerepet játszott az események kialakulásában. A személyi tényező esetében mind a témával kapcsolatos tudásnak, mind pedig a viselkedésnek (pl. szabályok betartása, megfelelö technikák használata, megfelelö kommunikáció) nagy jelentősége van. Ez alapján okkal feltételezhetjük, hogy a személyi tényező befolyásolásán keresztül - az ismeret bővítése, a viselkedés megváltoztatása által - az oktatás a magyar körülmények között is jelentős hatással lehet a megelőzésre.

A Cheetham és munkatársai által felvetett, az oktatások rövidtávú hatásával kapcsolatos nehézség [7] ellensúlyozása miatt is fontos lehet az oktatott ismeretek rendszeres felelevenítése, nem csupán azért, mert a hazai jogszabály évente kötelezően elvárja a képzések megtartását. Ha figyelembe vesszük a felejtés természetes folyamatát, valamint azt, hogy az egészségügyben használt eszközök gyakran változnak, fejlődnek, és azok kialakítása, helyes használata gyártónként eltérő lehet, érdemes megfontolni akár a kötelezőnél gyakoribb oktatás lehetőségét/szükségességét is. Ezek a plusz alkalmak lehetnek akár kevésbé formális oktatások is. Céljuk lehet a témával kapcsolatos figyelem fenntartása, az elsajátított helyes technikák rögzítése, az újonnan beszerzett eszközök helyes használatának gyakoroltatása, valamint az intézményben történt éles, hegyes eszközök okozta sérülések hátterében feltárt problémák megoldására hozott intézkedések bevezetése.
Az oktatott ismeretek frissen tartása, megőrzése érdekében a rendszeres ismétlésen túl hasznos eszköz lehet a legfontosabb tudnivalók posztereken történő kihelyezése is.

Az oktatások intézményi megszervezésekor nehézséget jelenthet, hogy a jogszabály ugyan megjelöli azt, hogy milyen témákról szükséges szót ejteni, de abban nem ad támpontot, hogy a képzés során az egyes témakörökhöz kapcsolódóan milyen ismereteket és milyen részletezettséggel kell átadni. Egy központilag kidolgozott részletes tananyag nagy segítséget nyújthatna az intézményi képzések szervezői számára. Érdemes emellett bátorítani az intézményeket arra is, hogy gyűjtsék a bekövetkezett sérülésekkel kapcsolatos adatokat (pl. a NEVES jelentési rendszer segítségével), majd saját adataikat elemezve igyekezzenek feltárni a problémák hátterében rejlő okokat, azonosítsák az intézményi gyengeségeket és a saját képzéseik során a hangsúlyokat ennek ismeretében határozzák meg.

A túszúrásos vagy vágásos sérülések megelőzését célzó oktatások tartalmának összeállításához további hasznos gondolatok találhatók még a fentiekben már hivatkozott tanulmányban [4].

Treviño és munkatársai javaslatát - amely szerint a hallgatókat az egyes gyakorlati helyszínek közötti váltás előtt helyszínspecifikus oktatásban célszerū részesíteni [9] - érdemes továbbgondolni. Hiszen ilyen oktatásra nem csupán a képzésben résztvevőknek lehet szükségük, hanem például a más munkaterületre ideiglenesen átirányított munkatársaknak is (lásd: COVID-19 járvány kapcsán végzett munkaerő-átcsoportosítások, kirendelések). Célszerú lehet munkaterületenként átgondolni, hogy melyek azok a speciális eszközök és helyzetek, amelyek a munkavégzés során fokozott kockázatot jelenthetnek, és hogy kik azok a személyek, akiket erről tájékoztatni szükséges, ideértve nemcsak a szakszemélyzetet és a hallgatókat, hanem a kiszolgáló tevékenységet végzőket is.

A képzés módját illetően számos lehetőség áll rendelkezésre, ám az eredményesség érdekében érdemes megfontolni, hogy mit válasszunk. Hazánkban is egyre inkább elterjedőben van az e-learning, ami sok téma esetében megfeleló választás. Aziz és munkatársai tapasztalatai azonban alátámasztják azt, hogy az éles, hegyes eszközök okozta sérülések megelőzését célzó oktatások során fontos a gyakorlati jellegű, személyes oktatás [8].

A képzés eredményességének méréséhez a képzés előtti és azt követő tudásszint-felmérés, valamint a két adatsor eredményeinek összehasonlítása lehet hasznos eszköz.

\section{KÖVETKEZTETÉSEK}

Az egészségügyben dolgozó munkatársak számára reális és jelentős kockázat a munka során használt éles, hegyes eszközök miatti sérülés bekövetkezése. Ennek kivédése érdekében számos megoldás született már, de a kockázatot egyik módszer sem tudja önmagában nullára csökkenteni. A megelőző intézkedések sorában kiemelt jelentősége van az oktatásnak, amely alapját képezi az új intézkedések bevezetésének, és a témával kapcsolatos ismeretek bővítését, a helyes viselkedés elsajátítását szolgálja (megfelelő technikák haszná- 
lata, megfelelő kommunikáció, szabálykövetés). Ezért is fontos, hogy az oktatás milyen eredményességgel valósul meg.

Annak érdekében, hogy a sérülések megelőzését célzó oktatások megfelelőek legyenek, érdemes felhasználni a már meglévő tapasztalatokat. A cikkben hivatkozott források alapján rendszeresen, legalább évenként ismétlődően szükséges a témával kapcsolatos képzéseket megtartani, lehetőleg gyakorlati képzés formájában, a munkaterületnek megfelelő speciális ismereteket beépítve. A képzés eredményességét az oktatást megelőzően és azt követően készített felméréssel lehet ellenőrizni. A képzés tartalmának kialakításához a vonatkozó jogszabály ad keretet, de a hangsúlyok meghatározásakor célszerủ az intézményi nehézségekből, problémákból és az azok megoldására kialakított intézkedésekből kiindulni. Ehhez szükség van a bekövetkezett sérülésekkel kapcsolatos adatok gyüjtésére és elemzésére a háttérben álló okok azonosítása érdekében. A munkához segítséget jelenthet az említett tanulmányon túl a Módszertani útmutató az oki kutatások készítéséhez címủ összefoglaló. Mindkét anyag elérhető az alábbi linken: https://info.nevesforum.hu/category/oki-kutatasok/.

A kutatás korlátai: A NEVES jelentési rendszerbe jelentett adatok önkéntes adatszolgáltatásból származnak, így az események előfordulási gyakoriságára vonatkozóan következtetéseket nem tudunk levonni. A MESZK-kel együttmükö- désben végzett kérdőíves felmérés nem reprezentatív, a nagyszámú válasz mégis érdemessé teszi ezeket az adatokat arra, hogy azokra alapozva következtetéseket és javaslatokat fogalmazzunk meg. Tekintettel arra, hogy a kutatásokban az események oki hátterét és megelőzési lehetőségeit vizsgáltuk és nem azok gyakoriságát, az említett korlátok a kutatás eredményeit nem befolyásolták.

Anyagi támogatás: A dolgozat alapjául szolgáló kutatás az Európai Unió által támogatott EFOP 1.8.0 - VEKOP 17 kiemelt pályázati konstrukció keretében készült. A publikáció elkészítése anyagi támogatás nélkül történt.

Szerzői munkamegosztás: S. L. A. E.: Irodalomkeresési stratégia meghatározása, részvétel a közlemény fö üzeneteinek meghatározásában és a közlemény megszövegezésében. B. Z.: Részvétel a közlemény fö üzeneteinek meghatározásában és a közlemény megszövegezésében. A kézirat végső változatának elkészítése a szerzők közös munkájának eredménye. A cikk végleges változatát valamennyi szerző elolvasta és jóváhagyta.

Érdekeltségek: A szerzőknek nincsenek érdekeltségeik.

\section{Köszönetnyilvánítás}

A szerzők ezúton mondanak köszönetet a cikk alapjául szolgáló kutatásban való közremüködésért a következőknek: Nemesné Singer Edina, Pató Edit, Pitás Eszter.

\section{IRODALOMJEGYZÉK}

[1] Balogh Z, Raskovicsné CsM, Hirdi H, Hundley V, Mészáros J: The incidence of needlestick injuries among health workers in Hungary. Journal of Medical Safety, 2014. 43-50.

[2] Kurcz A, Zemanovics G: Prevention of injuries caused by needlestick or sharp tools which are used in healthcare institutions. [Az egészségügyi intézményekben használt éles vagy hegyes eszközök által okozott sérülések megelözése.] Epinfo, 2014. 21. évfolyam 37. 449-457.

[3] Belicza É, Sinka LAE: A hibákból és a nemkívánatos eseményekből való tanulás - módszertani áttekintés a témaspecifikus tanulmányokhoz. IME. 2021/4. szám

[4] Sinka LAE, Pató E, Nemesné SE, Pitás E: Éles, hegyes eszközök okozta sérülések okai, a megelőzés lehetőségei. Semmelweis Egyetem Egészségügyi Menedzserképző Központ, Budapest, 2020.

https://info.nevesforum.hu/2020/02/eles-hegyes-eszkozok-okozta-serulesek-okai-a-megelozes-lehetosegei/ (megtekintve: 2021.11.18.)

[5] 51/2013. (VII. 15.) EMMI rendelet az egészségügyi szolgáltatás keretében használt, éles vagy hegyes munkaeszközök által okozott sérülések megelőzésére, az ilyen esz- közök használatából eredő kockázatok kezelésére, valamint az egészségügyi tevékenységet végző személyek tájékoztatására és képzésére vonatkozó követelményekröl. https://net.jogtar.hu/jogszabaly?docid=a1300051.emm (megtekintve: 2021.08.29.)

[6] Hassanipour S, Sepandi M, Tavakkol R et al.: Epidemiology and risk factors of needlestick injuries among healthcare workers in Iran: a systematic reviews and meta-analysis. Environ Health Prev Med. 2021. Apr 1;26(1):43. https://doi.org/10.1186/s12199-021-00965-x

[7] Cheetham S, Ngo HT, Liira J, Liira H: Education and training for preventing sharps injuries and splash exposures in healthcare workers. Cochrane Database Syst Rev. 2021. Apr 14;4(4):CD012060.

https://doi.org/10.1002/14651858.CD012060.pub2

[8] Aziz AM: Do training and needle-safety devices prevent needlestick injuries? A systematised review of the literature. Br J Nurs. 2018. Sep 6;27(16):944-952. https://doi.org/10.12968/bjon.2018.27.16.944

[9] Treviño H 2nd, Romero Arenas MA: Systematic Review of Blood-Borne Pathogen Exposure Rates Among Medical Students. J Surg Res. 2020. Nov;255:66-70. Epub 2020 Jun 14. https://doi.org/10.1016/j.jss.2020.05.032 


\section{A SZERZŐK BEMUTATÁSA}

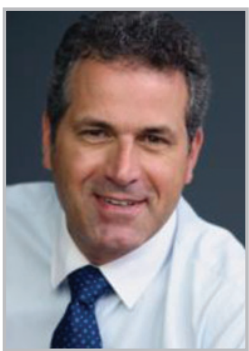

Dr. Balogh Zoltán a Magyar Egészségügyi Szakdolgozói Kamara alapító tagja, 2004 óta elnöke, a Semmelweis Egyetem Egészségtudományi Kar Ápolástan Tanszék tanszékvezető főiskolai tanára. Pályafutását a magyar egészségügyben 31 évvel ezelőtt segédápolóként kezdte. Szakmaterülete a neurológiai, pszichiátriai ápolás, a közösségi ellátás, az otthoni szakellátás és a rehabilitáció. Ehhez az alapot 1994-ben megszerzett diplomás ápoló kitüntetéses illetve az 1995-ben megszerzett gyógytornász oklevele mellett a fekvőbeteg-ellátás és az otthoni szakápolás területén eltöltött gyakorlata adta. Tudományos elömenetelét a brit Exeter Egyetemen 1997-ben az egészségügyi szakképzés területéről megszerzett (MSc) egyetemi diplomája alapozta meg. Tudományos fokozatát a Semmelweis Egyetem Doktori Iskolában szerezte 2008-ban. Hét éven keresztül volt a Magyar Ápolási Egyesület vezetőségének tagja, három évig elnöke. Számos szakmai és tudományos bizottság, testület aktív tagja. 2020-tól az Egészségtudományi Karon a klinika kapcsolatokért felelős dékánhelyettesi feladatokat látja el.

Sinka Lászlóné Adamik Erika bemutatása lapunk 17. oldalán olvasható.

\section{Hatások és ráhatások címmel szervezett V4 kulturális konferenciát az EMMI}

Példaértékü együttmüködés eredményeként egyedülálló konferenciát szervezett a magyar V4-elnökség keretén belül az Emberi Erőforrások Minisztériuma. A négy ország kulturális életének kormányzati vezetői kétnapos online konferencián osztották meg egymással tapasztalataikat a pandémia által előidézett helyzetről és a kultúra szerepéröl a járványkezelésben.

Kulturális innovációk és jó gyakorlatok a koronavírus idején témakörben szervezett kulturális konferenciát az Emberi Erőforrások Minisztériuma, melyen a V4 országok képviselői osztották meg tapasztalataikat egymással az elmúlt közel két év történéseire adott válaszreakciók kapcsán.

A kétnapos online konferencia részeként Viera Leščáková, Szlovák Köztársaság Kulturális Minisztériumának államtitkára, Vlastislav Ouroda, a Cseh Köztársaság Kulturális Minisztériumának miniszterhelyettese, Jarosław Sellin a Lengyel Köztársaság Kulturális, Nemzeti Örökség és Sport Minisztériumának miniszterhelyettese és államtitkára és Fekete Péter, az Emberi Erőforrások Minisztériumának kultúráért felelős államtitkára beszélt a jó gyakorlatokról és olyan hosszú távú projektekről, amelyek nem csak a pandémia alatt, hanem azután is részei lehetnek a kulturális intézmények életének.

A V4 együttműködés soros elnöke, Magyarország a járvány alatt a kultúra területén is jól teljesített, számos példát teremtve ezzel a nemzetközi szakmai partnereknek a járvány utáni élet újraindításához. A konferencia keretében összegyűjtött szakmai anyag célja, hogy a négy ország sikereit egész Európa megismerje, ezzel is ráirányítva a figyelmet az országok közötti együttmüködés sikerességére.

Magyar részről mintegy 15 intézmény vett részt a szakmai fórumon, a konferencia megmutatta, hogy a kultúra kellően kreatív ahhoz, hogy ebben a számára rendkívül nehéz időszakban is erősen hatással van a társadalmi jelenségekre és jelentős szerepet játszhat a járvány utáni élet újraindításában. 